Jahangirnagar University J. Biol. Sci. 7(2): 33-45, 2018 (December)

\title{
Investigation on a Bangladeshi isolate Bacillus aryabhattai for promising biotechnological applications
}

\author{
Mohammad Shahedur Rahman*, Rasheda Banu, Ripa Moni ${ }^{1}$, Nazmul Islam ${ }^{1}$, \\ Mastura Khatun Ruma and Umme Salma Zohora \\ Department of Biotechnology and Genetic Engineering, Jahangirnagar University, Savar, \\ Dhaka-1342, Bangladesh
}

\begin{abstract}
A new isolate was investigated from soil sample collected from Shahrasti upazilla of Chandpur district of Bangladesh. Based on the physico-chemical studies the strain was identified as gram positive Bacilli. Moleculer characterization of the strain was identified as Bacillus aryabhattai which is the first report in Bangladesh. The strain can survive in extreme conditions of salt, temperature and $\mathrm{pH}$. This strain was further characterized and screened for the ability to produce useful enzymes. The optimum temperature for growth and production of these enzymes was within the temperature range $35^{\circ} \mathrm{C}$ to $40^{\circ} \mathrm{C}$. The $\mathrm{pH}$ was found to be 7 for its growth and production of different enzymes when investigated over $48 \mathrm{~h}$ of incubation. The isolate produced various extracellular enzymes such as $\alpha$-amylases, cellulases, $\beta$-glucosidases, lipases and proteases. The findings of this study provide useful information of the new strain that has potential biotechnological applications.
\end{abstract}

Keywords: Bacillus aryabhattai, $\alpha$-amylase, protease, lipase, cellulase, $\beta$-glucosidase

\section{INTRODUCTION}

Cosmic ancestry is a new theory trying to explain the evolution and the origin of life on earth. It studies the life on earth was seeded from space, and that life's evolution to superior forms depends on genetic foundations that come from space. It is a testable theory for which evidence is increasing. Panspermia hypothesis describes that life on earth is originated from the outer space. The particular version of this theory known as "cometary panspermia", arguing that comets throughout the universe are the incubators and transporters of life, was first anticipated in the 1970's by the Sri Lankan astronomer Chandra Wickramasinghe together with the British astronomer Sir Fred Hoyle (Hoyle \& Wickramasinghe, 1977, 1981, 2000; Line 2007, Napier et al., 2007). It is now believed that space contains the ingredients of life, sometimes in chemical form, sometimes in the form of an organism (Arrhenius, 2009; Hoyle \& Wickramasinghe, 2000; Wainwright, 2010; Wickramasinghe et al., 2009). This development could be the hints of huge paradigm shift or evidence of panspermia - where - bacteria can survive in harsh environment - away from earth like outer space. The strain Bacillus aryabhattai was first reported in the subcontinent by the Indian authors where the sample was collected from high-altitude air samples (altitude 20-41.4 km) (Shivaji et al., 2009). Since then this

\footnotetext{
${ }^{1}$ Present address: Eskayef Pharmaceuticals Ltd., 400 Squib Road, Tongi Industrial Area, Tongi, Gazipur 1711, Bangladesh

*Corresponding author. E-mail: rahmanms@juniv.edu
} 
bacterium is used to termed as space organism relating panspermia. Later B. aryabhattai was also reported by other authors in this subcontinent where it was collected from the rhizosphere region of Lemna sp. in 2012 (Ray et al., 2012).

As a result of random experiment, from a soil sample from Chandpur of Bangladesh, a new bacilli was isolated. From molecular identification and phylogenetic tree analysis it was revealed that the strain was $B$. aryabhattai. We believe that this is the first report in Bangladesh with $B$. aryabhattai that is found to be available in soil - not in space. In this report our study deals with screening of suitable organisms with potential biotechnological applications. Selection of the right organism plays a key role in high yield of desirable biotech products, like enzymes. For production of industrial enzymes, isolation and characterization of new promising strains using cheap carbon and nitrogen sources is a continuous process. This report describes that $B$. aryabhattai is also available in earth soil and it has potential biotechnological applications as we have screened for different industrially important enzyme production by the novel isolate.

\section{MATERIALS AND METHODS}

\section{Isolation of bacteria from soil sample}

Sample Collection: The soil samples were collected from Shahrasti upazilla of Chandpur district. Soil, sediment and ground water in the area have been contaminated with arsenic for many years. Soil samples were collected aseptically from the sub-surface (from 0 to $15 \mathrm{~cm}$ in depth from ground) in sterile sample bottles and kept in $4^{\circ} \mathrm{C}$ until further analysis. For isolation of bacteria firstly $2 \mathrm{~g}$ soil sample were mixed with $50 \mathrm{ml}$ autoclaved distilled water.

Strain isolation: One gram of each soil sample was taken in $100 \mathrm{ml}$ of $0.1 \mathrm{M}$ phosphate buffer solution and mixed well by vortexing for 3 minutes. Each Sample was serially diluted with sterile saline water $(0.85 \%)$ and plated on Yeast Extract Mannitol (YEM) agar medium $\left\{\right.$ D-Mannitol (Qualikems, India), $10 \mathrm{~g} ; \mathrm{K}_{2} \mathrm{HPO}_{4}$ (Scharlau, Spain), $0.5 \mathrm{~g}$; $\mathrm{MgSO}_{4}$. $7 \mathrm{H}_{2} \mathrm{O}$ (MERCK, India), $0.2 \mathrm{~g}$; $\mathrm{CaCl}_{2}$ (Scharlau, Spain), $0.1 \mathrm{~g}$; yeast extract (TM MEDIA, India), $0.5 \mathrm{~g}$; phosphate buffer solution, up to $1000 \mathrm{ml}, \mathrm{pH}$ 7.0. The plates were then incubated at $37^{\circ} \mathrm{C}$ for 48 hours. Pure cultures of different bacterial strains were obtained by successive isolation of morphologically different colonies through repeated cross streaking (Bergey et al. 1984).

Identification of bacterial isolates: After single colony isolation, the morphological, biochemical and molecular characteristics of the isolated bacterial strains were evaluated. Color, gram stain and cell morphology were investigated under microscope (Optika B350) (1000X magnification). Biochemical properties of the selected bacterium were tested according to Bergey's Manual of Systemic Bacteriology (Bergey, et al., 1984). The following biochemical tests were performed: Methyl Red (MR) test, Voges-Proskaur (VP) test, catalase test, glucose, fructose, sucrose, maltose, mannitol fermentation test, indole, citrate, gelatin and nitrate reduction test (Cappucino, et al., 2001). Molecular characterization was done by $16 \mathrm{~S}$ rRNA sequence analysis. Genomic DNA was extracted 
by automated DNA extractor (Model: Maxwell 16, Origin: Promega, USA) and qualified by Nanodrop Spectrophotometer (Model: ND2000, Origin: Thermo Scientific, USA). The $16 \mathrm{~S}$ rDNA from the extracted DNA was amplified by PCR using 27F (5'AGAGTTTGATCCTGGCTCAG-3') and 1492R (5'-ACGGCTACCTTGTTACGACTT3') primers. The reaction mixture composed of $12.5 \mu 1$ Hot Start Master Mix (Origin: Promega, USA), $1 \mu 1$ extracted genomic DNA, $1 \mu 1$ 37F primer (concentration $10 \mathrm{pMol}$ ), $1 \mu 1$ 1492R primer (concentration $10 \mathrm{pMol}$ ), $9.5 \mu 1$ nuclease free water. PCR was done by Gene Atlas (Model: G2, Origin: Astec, Japan). PCR profile was as follows: initial denaturation at $95^{\circ} \mathrm{C}$ for 3 minutes, followed by 35 cycles of denaturation $\left(95^{\circ} \mathrm{C}, 30\right.$ seconds), annealing $\left(48^{\circ} \mathrm{C}, 30\right.$ seconds), extension $\left(72^{\circ} \mathrm{C}, 1\right.$ minute) and final extension at $72^{\circ} \mathrm{C}$ for 5 minutes. To confirm amplification gel electrophoresis was done using agarose, 100 bp DNA ladder, ethidium bromide, TAE buffer, all from Promega, USA. Gel documentation was done by Alpha Imager (Model: Mini, Origin: Protein Sample, USA). Sequencing was performed by ABI 3700 Genetic Analyzer, 1st Base Laboratory SdnBhd, Malaysia. The 16S rDNA gene sequence was BLAST searched against GenBank database (http://www.ncbi.nlm.nin.gov/) and phylogenetic analysis was performed using Mega6tree explorer after multiple alignment by BioEdit software.

Growth at different temperatures: In order to study the effect of temperature on bacterial growth, cultivation temperature of the selected isolate was adjusted to $30^{\circ} \mathrm{C}$, $35^{\circ} \mathrm{C}, 37^{\circ} \mathrm{C}, 40^{\circ} \mathrm{C}$ and $47^{\circ} \mathrm{C}$. After 16 hour of incubation the absorbance was measured at $660 \mathrm{~nm}$.

Growth at different $\mathbf{p H}$ levels: In order to determine the appropriate $\mathrm{pH}$ on bacterial growth, the $\mathrm{pH}$ of the medium was adjusted to different $\mathrm{pH}$ level ( $\mathrm{pH} 4$ to 10). After 16 hour of incubation the absorbance was measured at $660 \mathrm{~nm}$.

Growth at different salinities: To determine the appropriate salt concentration for the growth of B. aryabhattai, LB medium with different concentration of salt (1\% to $7 \%$ ) having $\mathrm{pH} 7$ were prepared. After 16 hour of incubation the absorbance was measured at $660 \mathrm{~nm}$.

Amylolytic activity assay: Bacterial colonies first grown on $1 \%$ starch plate beef extract $3 \mathrm{~g} / \mathrm{L}$, starch $10 \mathrm{~g} / \mathrm{L}$, agar $12 \mathrm{~g} / \mathrm{L} \mathrm{pH} 7.5 \pm 0.2$ (at $25^{\circ} \mathrm{C}$ ) \}. Amylase activity can be detected by flooding the plates of 48 hours old culture on starch agar with iodine complex. Amylase positive organisms show clear zone around colony while development of blue to purple zone indicates starch is not hydrolyzed. Size of the clear zone is directly proportional to the starch hydrolyzing activity of the strain (Islam et al., 2017).

Proteolytic activity assay: Skim milk agar plates (SMA) are used for providing nutrition and for the detection of proteolytic activity of microorganisms. SMA is composed of skim milk powder $(28 \mathrm{~g} / \mathrm{L})$, casein enzymichydrolysate $(5 \mathrm{~g} / \mathrm{L})$, Yeast extract $(2.5 \mathrm{~g} / \mathrm{L})$, dextrose $(1 \mathrm{~g} / \mathrm{L})$, agar $15(\mathrm{~g} / \mathrm{L})$ with final $\mathrm{pH}$ 7. The plates are inoculated with a population of microorganisms to test for the ability to digest casein hydrolysis (Rahman et al., 2018). 
Cellulytic activity assay: For primary screening of cellulytic activity, purified strains were inoculated in $5 \mathrm{ml}$ of number 3 medium. After $24 \mathrm{~h}$ incubation at $37^{\circ} \mathrm{C}$ in water bath (VS-1205SW1, Korea), $5 \mu \mathrm{l}$ of culture was transferred in CMC agar plates (CMC 1\%, peptone $3 \%, \mathrm{KH}_{2} \mathrm{PO}_{4} 0.1 \%, \mathrm{MgSO}_{4} 0.01 \%$ and agar $2 \%$ with $\mathrm{pH} 6.8$ ). $\mathrm{CMC}$ plates were incubated at $37^{\circ} \mathrm{C}$ for 24 to 48 hour. After incubation formation the plates were flooded with gram's iodine solution and washed with $70 \%$ alcohol.

Lipolytic activity assay: Tributyrin agar (TBA) is a differential agar medium (peptone, 5 $\mathrm{g}$; beef extract, $3 \mathrm{~g}$; tributyrin, $10 \mathrm{ml}$ and agar-agar, $20 \mathrm{~g}$ per litre ) that tests the ability of a strain to produce an exoenzyme, called lipase and hydrolyzes tributyrin oil. At first the strain was inoculated in TBA plates and grown at $37^{\circ} \mathrm{C}$ for 24 to 48 hour. Lipase allows the microorganisms that produce it to break down lipids into smaller fragments and forms a clear halo surrounding the areas where the lipase-producing organism has grown.

Secondary Screening for extracellular enzymes: For secondary screening, the isolate was cultured on freshly prepared different mediums according to enzymes to be screened. After 24 hours of culture, submerged fermentation conical flasks were taken off from the incubator and shaking water bath, homogenize fermented culture using homogenizer (IKA®T10, Germany) for 15 seconds. Then the homogenized cultures were centrifuged at $10000 \times \mathrm{g}$ for 20 minutes using bench top centrifuge machine (Eppendorf 5418, Germany) and supernatants were collected. These supernatants were used as crude enzymes for measuring enzyme assays.

Amylase assay: A colorimetric method was used to measure the $\alpha$-amylase activity with 3,5-dinitrosalicylic acid (DNS) reagent. After $16 \mathrm{~h}$ culture in number 3 medium (polypeptone $30 \mathrm{~g}$, starch $10 \mathrm{~g}, \mathrm{KH}_{2} \mathrm{PO}_{4} 1 \mathrm{~g}$ and $\mathrm{MgSO}_{4} 0.5 \mathrm{~g}$ per litre) the culture was centrifuged and supernatant was used for assay. In this method, starch is converted into glucose by $\alpha$-amylase. Glucose released from starch was measured by the reduction of 3,5-dinitrosalicylic acid. DNS binds with glucose and changes color. This intensity change in color was measured using a spectrophotometer as the absorbance at $575 \mathrm{~nm}$ wavelength. Wave length was set to $575 \mathrm{~nm}$ because it is the region where orange-red color absorbs. $1 \mathrm{mg}$ per $\mathrm{ml}$ of enzyme carries 30 unit of activity. Sodium acetate was used to soluble the control enzyme. $500 \mu$ l starch $(1 \%)$ is mixed with $500 \mu$ l of enzyme in a test tube and used as control. $1 \mathrm{ml}$ of only starch is taken in another test tube. Both tubes were incubated for $30 \mathrm{~min}$ at $37^{\circ} \mathrm{C}$ on water bath shaker. $500 \mu \mathrm{l}$ of each solution was taken and mixed with $500 \mu \mathrm{l}$ of DNS in two tubes. Tubes were kept for $10 \mathrm{~min}$ at $90^{\circ} \mathrm{C}$ in water bath. Immediately $250 \mu 1$ of $40 \%$ Rochelle's salt was added in both tubes and cooled down to room temperature. Absorbance was measured at $575 \mathrm{~nm}$.

Protease assay: To determine the activity of protease, azocasein protease assay was done. $200 \mu 1$ of overnight selected bacterial culture aliquot was transferred to $100 \mathrm{~mL}$ conical flask containing $20 \mathrm{ml}$ No. 3 medium [Peptone- 3\% (Uni-chem, china), DGlucose- $1 \%$ (Merck, Germany), $\mathrm{KH}_{2} \mathrm{PO}_{4}-0.1 \%$ (Scharlau, Spain), $\mathrm{MgSO}_{4} .7 \mathrm{H}_{2} \mathrm{O}-0.05 \%$ (Merck, India), pH- 6.8]. Then the conical flasks was kept in shaking water bath (Model: VS-1205SW1, Origin: Vision Scientific Co., Ltd, Korea) at $37^{\circ} \mathrm{C}, 120 \mathrm{spm}$ for submerged 
fermentation. After 24 hours, the conical flask was taken off from the shaking water bath, homogenized the culture using homogenizer (IKA ${ }^{\circledR} \mathrm{T} 10$ basic, Germany) for 15 seconds. Then the homogenized culture was centrifuged at 10000xg for 20 minutes using bench top centrifuge machine (Eppendorf 5418, Germany) and supernatant were collected. This supernatant was used as crude enzymes for measuring protease activity.

To measure protease activity of the crude enzymes, $100 \mu 1$ of $1 \%$ azocasein $[0.1 \mathrm{~g}$ azocasein (Sigma, Germany) dissolved in $10 \mathrm{ml}$ phosphate buffer solution] was added to $200 \mu 1$ of crude enzyme, mixed well by vortexing and incubated at $37^{\circ} \mathrm{C}$ for 30 minutes. Then $700 \mu 1$ trichloroacetic acid (TCA) (BDH, London) was added and kept on ice for 20 minutes. After centrifugation at $15000 \mathrm{x}$ g for 5 minutes, $600 \mu \mathrm{l}$ supernatant was added to $600 \mu 10.5 \mathrm{M}$ sodium hydroxide (Merck, Germany) and measured optical density (OD) at $440 \mathrm{~nm}$ using spectrophotometer (Mecasys Optizen Pop UV/Vis Spectrophotometer, Korea). Blanks were prepared by following the same procedure except crude enzymes were added after adding TCA. From the $\mathrm{OD}_{440}$, enzyme activity (units $/ \mathrm{ml}$ ) was measured. One unit is defined as change in absorbance at $440 \mathrm{~nm}$ of 0.01/hours (Kohlmann et al., 1991).

Cellulase assay: By using a method described by Miller (1959) with some modifications (Wood \& Bhat 1988), the carboxy methyl cellulase activity was assayed. In this assay, $500 \mu 1$ crude enzyme was mixed with $500 \mu 1$ of substrate (1\% CMC) in a test tube. In the negative control, $500 \mu 1$ substrate was mixed with $500 \mu 1$ citrate buffer and in positive control $500 \mu \mathrm{l}$ standard cellulase enzyme was mixed with $500 \mu \mathrm{l}$ of substrate. The tubes were incubated at $60^{\circ} \mathrm{C}$ for $30 \mathrm{~min}$ in incubator. The reaction was stopped by the addition of $2 \mathrm{ml}$ of DNS reagent and subsequently incubating the tubes at $90^{\circ} \mathrm{C}$ for $15 \mathrm{~min}$. After incubation $1 \mathrm{ml}$ of $40 \%$ Rochelle salt was added and kept in ice to stabilize the color for 2 min. The absorbance was measured at $575 \mathrm{~nm}$.

$\boldsymbol{\beta}$-glucosidase activity: To assay $\beta$-glucosidase activity p-nitrophenyl- $\beta$-D glucopyranoside (pNPG) was used as substrate. $375 \mu 1$ crude enzyme was mixed with 50 $\mu \mathrm{l}$ of pNPG and $75 \mu \mathrm{l}$ of sodium acetate buffer $(2 \mathrm{M}, \mathrm{pH} 5.0)$ and incubated at $50^{\circ} \mathrm{C}$ for $10 \mathrm{~min}$ in hot water bath. To terminate the reaction $1750 \mu \mathrm{l}$ of $1 \mathrm{M} \mathrm{Na}_{2} \mathrm{CO}_{3}$ was added. The developed yellow color was read at $410 \mathrm{~nm}$ against negative control using a spectrophotometer (Neesa et al., 2017).

Lipase assay: With modified methods of Lee et al.(1999), the lipase activity was determined spectrophotometrically. To prepare the reaction solution $100 \mathrm{mM}$ potassium phosphate buffer ( $\mathrm{pH} 7.0)$, ethanol and $50 \mu \mathrm{M}$ para- nitrohenyl palmitate ( $p$-NPP) at a concentration of 95:4:1 was mixed. To carry enzymatic reaction the test tubes were inoculated at $60^{\circ} \mathrm{C}$ for $15 \mathrm{~min}$ and the reaction stopped by storing the solution at $-20^{\circ} \mathrm{C}$ for $8 \mathrm{~min}$ in order to cool down. The release of $p \mathrm{NP}$ (para-nitrophenol) at $400 \mathrm{~nm}$ was measured, and one unit of enzyme was defined as the amount of enzyme needed for the hydrolysis of $1 \mu \mathrm{M} p$-NPP per minute at $60{ }^{\circ} \mathrm{C}, \mathrm{pH} 7.0$ (Koc et al., 2015). 


\section{RESULTS AND DISCUSSION}

DNA quantification: DNA quantification was done to determine the amount of DNA in the sample. From novel bacterial isolates genomic DNA was extracted and quantified by Nanodrop Spectrophotometer and PCR was done by Takara PCR thermal cycler. The concentration of DNA (ng/ $\mu \mathrm{l}$ ) was 2.7 and the $260 / 280$ ratio was 2.42 which means that DNA sample was not pure and RNA contamination was present. The 260/230 ratio was 0.63 which indicated possible other contaminants absorbing light $230 \mathrm{~nm}$ or less.

Agarose gel analysis of genomic DNA: Isolated DNA of the bacteria obtained from soil sample was loaded, PCR product in Lane 2 and $1 \mathrm{~kb}$ DNA Ladder was loaded on Lane 1. To visualize the band size agarose gel analysis was performed. It was observed that the PCR product of genomic DNA of isolate fall within the size range approximately $1500 \mathrm{bp}$ when compared to $1 \mathrm{~kb}$ DNA Ladder (Marker DNA) (Figure 1).

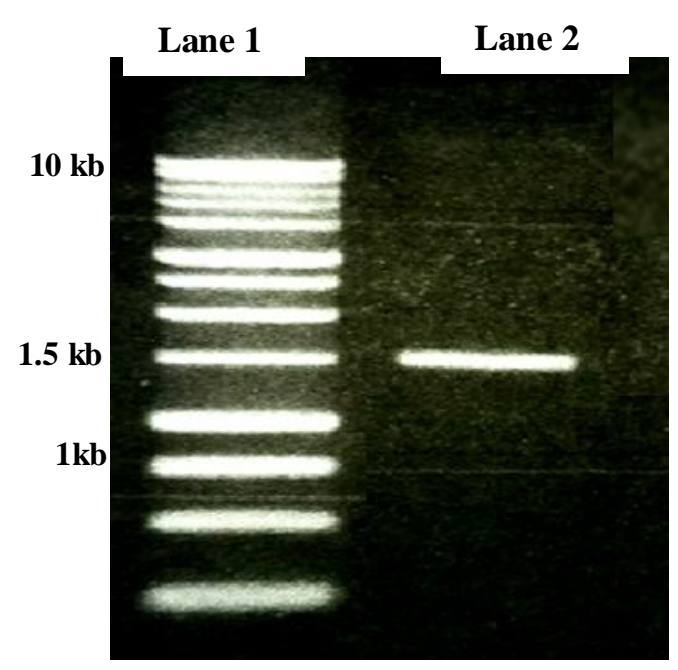

Fig. 1. Agarose gel analysis of genomic DNA and PCR product of genomic DNA of arsenic metabolizing bacteria with Marker DNA (1kb DNA Ladder)

16S rRNA gene sequences analysis: 16S rRNA gene was used for the identification of the bacterial isolate. This gene is highly conserved and encodes a component of the small subunit in the ribosome. Sequences were compared to other sequences from the genetic nucleotide library by using BLAST. The 16S rRNA gene sequences size was modified for the sample by eliminating undefined nucleotides at the beginning of the sequences because the peaks on those sections were not well defined. The nucleotide sequences coding for the 16S rRNA gene after BLAST query revealed that this gene is $99.93 \%$ homologous to B. aryabhattai (Table 1). 
Table 1. BLAST analysis results for $B$. aryabhattai strain

\begin{tabular}{|c|c|c|c|c|}
\hline Bacterial strains & $\begin{array}{l}\text { Total } \\
\text { Score }\end{array}$ & $\begin{array}{c}\text { Identity } \\
\text { (Nucleotide nos) }\end{array}$ & $\begin{array}{c}\text { Identity } \\
(\%)\end{array}$ & $\begin{array}{l}\text { Accession } \\
\text { Number }\end{array}$ \\
\hline Bacillus aryabhattai strain B8W22 & 2621 & $1421 / 1422$ & $99.93 \%$ & NR 115953.1 \\
\hline $\begin{array}{l}\text { Bacillus megaterium strain NBRC } \\
15308\end{array}$ & 2610 & $1419 / 1422$ & $99.78 \%$ & NR 112636.1 \\
\hline Bacillus flexus strain SBMP3 & 2531 & $1406 / 1423$ & $98.81 \%$ & NR 118382.1 \\
\hline Bacillus qinqshengii strain G19 & 2484 & $1398 / 1424$ & $98.17 \%$ & NR 133978.1 \\
\hline Bacillus simplex strain DSM 1321 & 2444 & $1362 / 1382$ & $98.56 \%$ & NR 115603.1 \\
\hline Bacillus paraflexus strain $\mathrm{RC} 2$ & 2364 & $1358 / 1393$ & $97.48 \%$ & NR 135732.1 \\
\hline Bacillus pocheonensis strain Gsoil 420 & 2326 & $1373 / 1427$ & $96.21 \%$ & NR 041377.1 \\
\hline $\begin{array}{l}\text { Bacillus bataviensis strain NBRC } \\
102449\end{array}$ & 2326 & $1370 / 1427$ & $96.01 \%$ & NR 109068.1 \\
\hline Bacillus cohnii strain DSM 6307 & 2307 & $1367 / 1425$ & $95.93 \%$ & NR 026138.1 \\
\hline Bacillus depressus strain DZ1 & 2303 & $1368 / 1426$ & $95.93 \%$ & NR 146034.1 \\
\hline Bacillus circulans strain ATCC 4513 & 2303 & $1368 / 1426$ & $95.93 \%$ & NR 104566.1 \\
\hline Bacillus herberstainensis strain D-1,5 & 2300 & $1369 / 1430$ & $95.73 \%$ & NR 042286.1 \\
\hline
\end{tabular}

Phylogenic analysis: The 16S rRNA sequences of the novel strain subjected to nucleotide BLAST query. Based on the sequence alignment, a phylogeny tree was found. Evolutionary analysis was conducted in MEGA6. The evolutionary history was inferred using the Neighbor-Joining method. The key, 0.002 indicates nucleotides per site that gives a measure of the scale of the genetic distance between each species (Table 2). Because of the fact that genetic distance is proportional approximately to time it can be said that the novel strain and $B$. aryabhattai are closely related and comes from a common ancestral species than other members of the node.

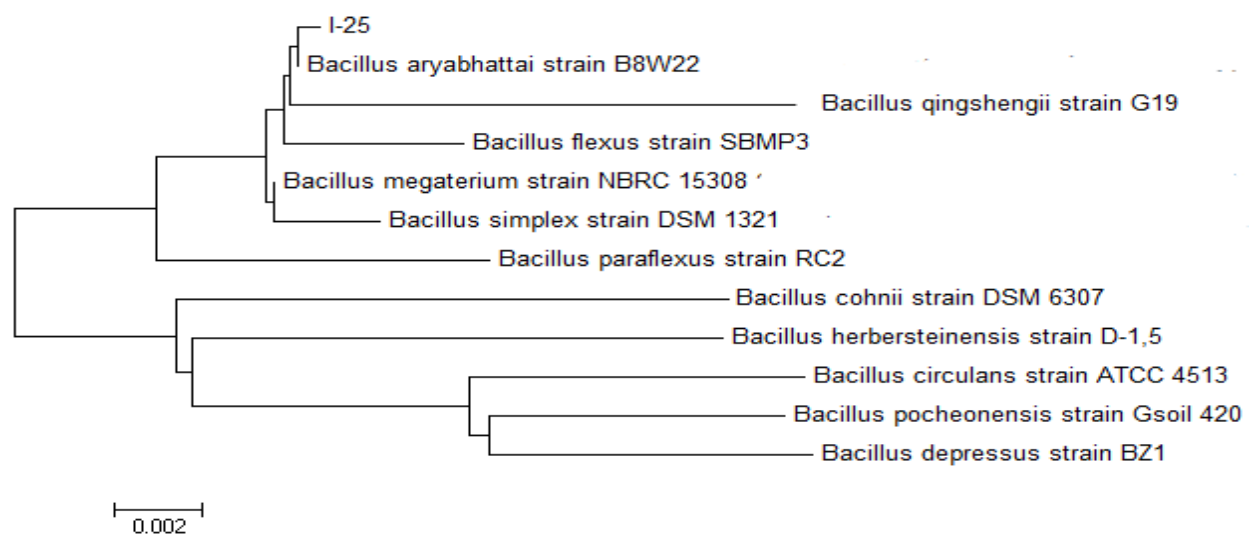

Fig. 2. Phylogenetic tree based on 16S rRNA gene sequences. The relationship between the novel strain with other related bacteria showed using phylogenic tree based on $16 \mathrm{~s}$ rRNA gene sequences 
Table 2. Physicochemical characteristics of B.aryabhattai

\begin{tabular}{lc|}
\hline Tests & B.aryabhattai \\
\hline Gram staining & $+\mathrm{Ve}$ \\
Shape & Rod Shaped \\
Methyl Red (MR) Test & $+\mathrm{Ve}$ \\
Voges-Proskaur (VP) Test & $+\mathrm{Ve}$ \\
Catalase Test & $+\mathrm{Ve}$ \\
Urease Test & $-\mathrm{Ve}$ \\
Oxidase Test & $-\mathrm{Ve}$ \\
Citrate Test & $-\mathrm{Ve}$ \\
Gelatin Test & $+\mathrm{Ve}$ \\
Nitrate Reduction Test & $+\mathrm{Ve}$ \\
\hline Note: +ve = positive result $\quad-v e=$ negative result
\end{tabular}

Growth at different temperature and $\mathbf{p H}$ : The isolate grew at various temperatures ranging from $30^{\circ} \mathrm{C}$ to $45^{\circ} \mathrm{C}$. From this observation it was found that this strain was similarly grown better at $37^{\circ} \mathrm{C}$ in comparison to other incubation temperatures (Figure 3). For optimum $\mathrm{pH}$ determination, the cultures were incubated overnight following inoculation at $37^{\circ} \mathrm{C}$. It was observed that the can frequently grow above the neutral $\mathrm{pH}$ as it was conducted up to $\mathrm{pH} 10$ (Figure 4). The optimum $\mathrm{pH}$ for growth was found to be at neutral and gradually decreased. The strain was unable to grow at $\mathrm{pH} 4$ as the growth profile indicates the likeliness of the strain in neutral to alkaline condition.

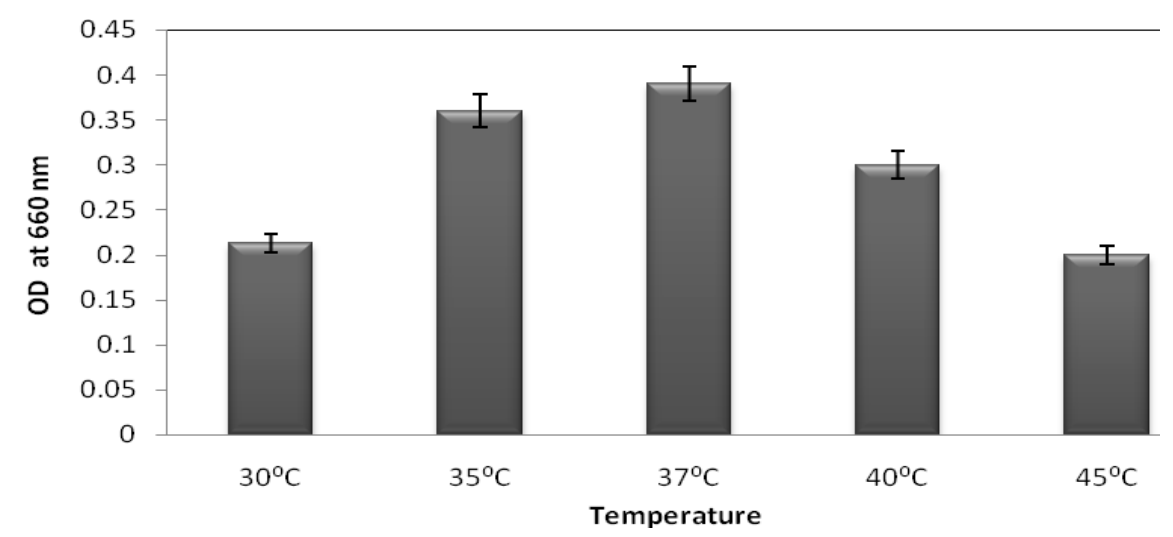

Fig. 3. Growth of $B$. aryabhattai at different temperature. Number of independent experiments $(\mathbf{n} \geq 3)$

Growth at different salinities: The new strain was able to grow in a range of salty condition. When it was cultured at different salinity $(\mathrm{NaCl})$ levels, the isolate grew well within salinity range of $1 \%-5 \%$ (Figure 5). Further increase of salt concentration sharply reduced the growth of the cell when culture was investigated after overnight incubation at $37^{\circ} \mathrm{C}$. As the new B. aryabhattai showed growth in different ranges of temperature, salt concentration and alkaline conditions. These characteristics indicates B. aryabhattai in category of haloalkaliphiles. 


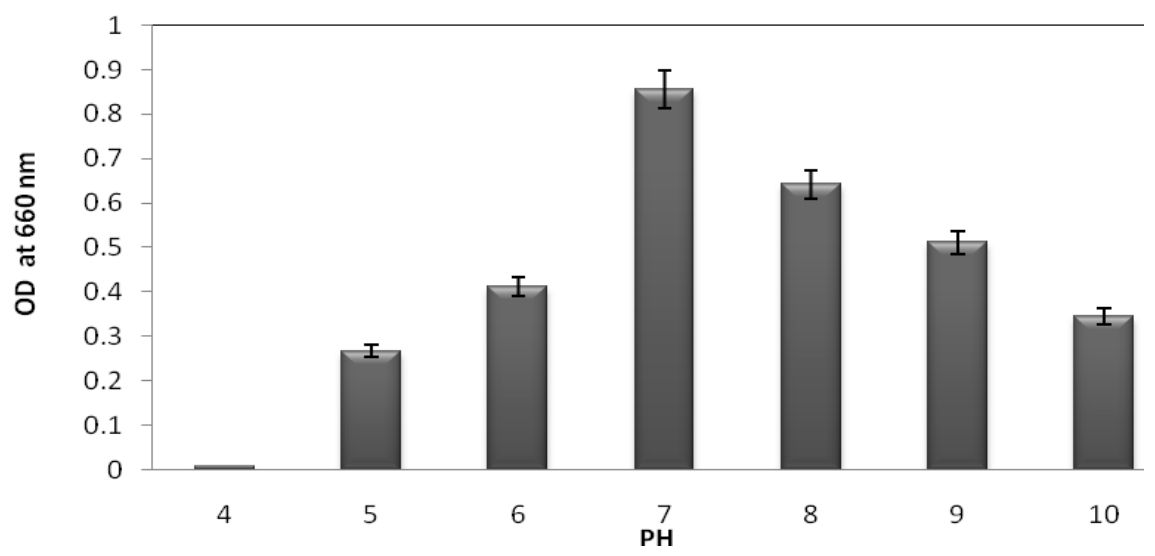

Fig. 4. Growth of bacteria $B$. aryabhattai at different $\mathrm{p}^{\mathrm{H}}$ level. Number of independent experiments $(n \geq 3)$

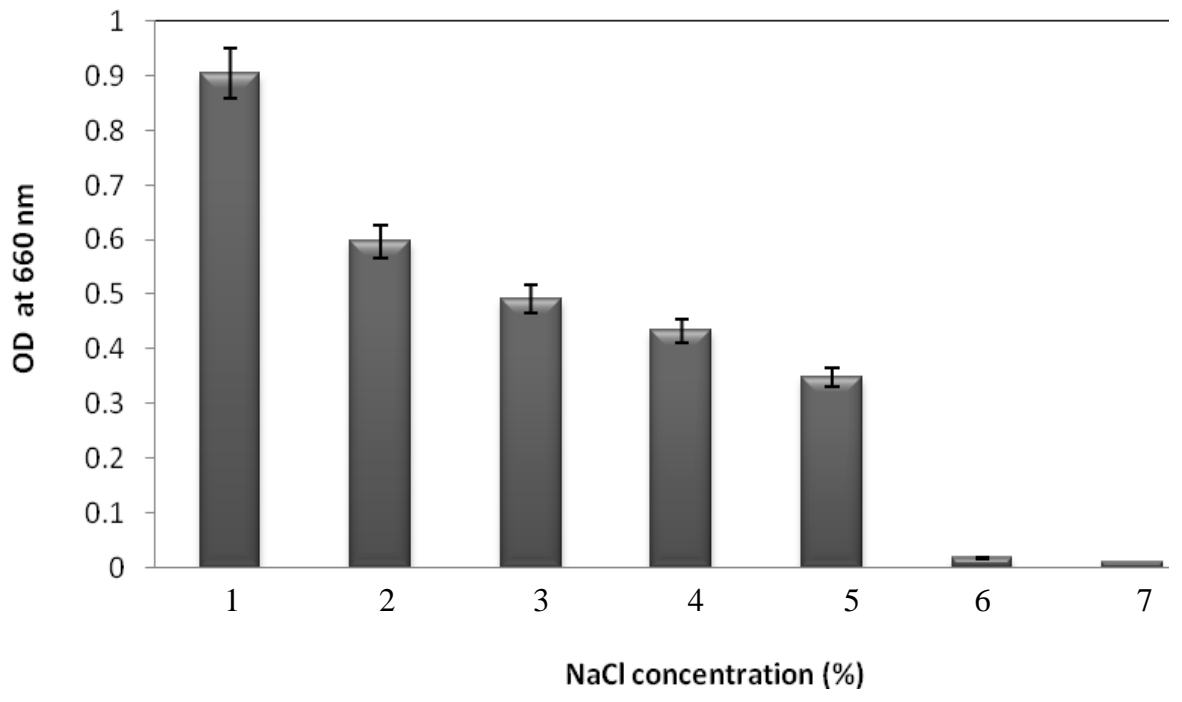

Fig. 5. Growth of $B$. aryabhattai at different $\mathrm{NaCl}$ concentration. Number of independent experiments $(n \geq 3)$

Enzymatic activity screening: Bacterial colonies were grown on 1\% starch agar plate. After 24 hour of incubation the plates were flooded with Gram's iodine (Gram's iodine$250 \mathrm{mg}$ iodine crystals added to $2.5 \mathrm{gm}$ potassium iodide solution) to produce a deep blue colored starch -iodine complex. In the zone of degradation no blue color formed, which is the basis of the detection and screening of an amylolytic strain (Figure $6 \mathrm{~A}$ ). In the assay for $\alpha$-amylase, glucose released from starch was measured by the reduction of 3, 5dinitrosalicylic acid (Miller, 1959). This intensity change in color is measured using a 
spectrophotometer as the absorbance at $575 \mathrm{~nm}$ wavelength. When compared the standard $\alpha$-amylase enzyme it was observed that the crude sample is resulted with 0.298 units of absorbance compared to 0.471 (Figure 7 A). As a first screening data, this information was quite impressive.
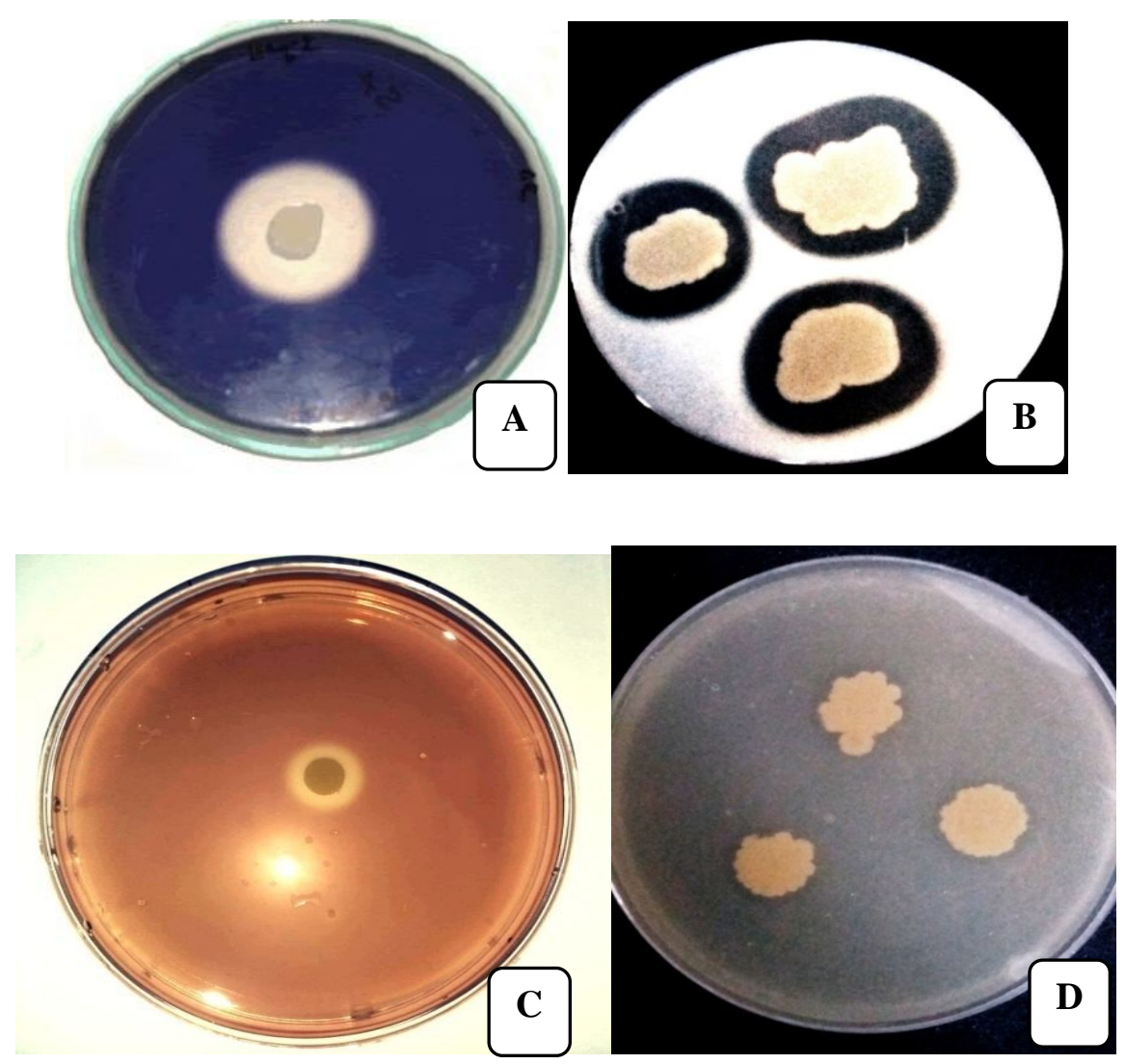

Fig. 6. Primary Screening of enzymes (A. Amylase on starch plate, B. Protease on SMA plate, C. Cellulase on CMC plate and D. Lipase on TBA plate)

In regular screening tests for proteolytic bacteria in agar plates hydrolyzed casein and formed soluble nitrogenous compounds indicates clear zone surrounding the colonies. In our investigation, a clear zone of casein hydrolysis indicates the strong proteolytic activity of the isolate (Figure $6 \mathrm{~B}$ ). Azo-casein assay for proteolytic enzyme activity resulted with about eighty percent activity with that of the standard enzyme used (Figure 7 B). The production of protease by this strain show significant promise in biotechnological applications.

The new isolate was tested on CMC agar plate for cellulase activity and formed clear zones after application of Gram's iodine solution indicated cellulose digestion by the production of cellulase enzyme in the corresponding bacterial strain. CMCase (using 1\% 
CMC as a substrate) assay resulted with absorbance of 0.292 while the positive control resulted with 0.437 . This result is interesting as well because this will facilitate us to use this organism for increasing demand cellulolytic enzyme production. The $\beta$-glucosidase productivity of the strain was further investigated, and noticeably the strain resulted with the absorbance of $p$-nitrophenol of 0.227 compared to the control enzyme that resulted with 0.483 units of absorbance (Figure $7 \mathrm{D}$ ).

In the TBA plate assay, lipase/esterase producing microorganisms produced a zone of clearance (hydrolysis) when their appropriate dilutions were spreaded on the TBA plates (Figure $6 \mathrm{D}$ ). The novel strain resulted with slight activity as it was seen the agar plate that was also verified with the spectrophotometric assay (Figure $7 \mathrm{E}$ ).
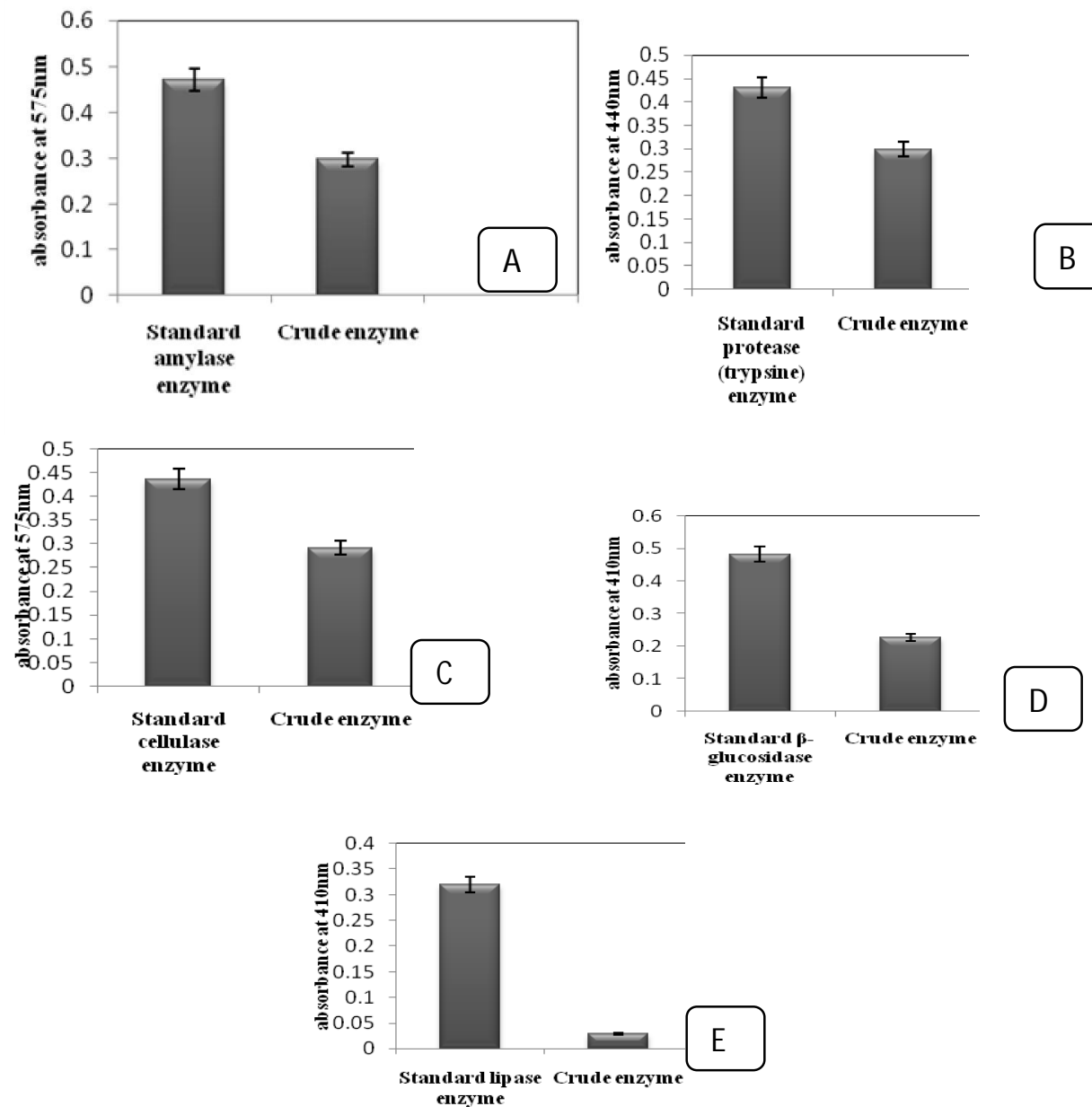

Fig. 7. Comparison of the activity of the standard enzymes and crude enzymes produced by B.aryabhattai (A. a-Amylase, B. Protease, C. Cellulase, D. B-glucosidase and E. Lipase) ( $(\mathbf{3})$ 
Bacillus is well known for its production ability of different industrially important enzymes like amylase (Souza \& Magalhaes 2010, Das et al., 2011); proteases (Gupta et al., 2002); cellulases (Li \& Yu, 2012); lipase (Horikoshi, 1999) etc. But in these cases different strains were reported for their production of respective enzymes. In our study this new strain of $B$. aryabhattai was primarily screened for four most industrially useful enzymes and showed excellent result with amylase, protease and cellulase but poor in lipase.

The bacterium isolated in this study was identified as B. aryabhattai from its phylogenetic analysis of $16 \mathrm{~S}$ rRNA sequence. This novel strain was primarily screened for four useful enzymes. It showed excellent production results for amylase, protease and cellulase but poor for lipase. The isolate was grown in different ranges of temperature, $\mathrm{pH}$ and salt concentrations. The optimum growth was observed at $37^{\circ} \mathrm{C}$, at $\mathrm{pH} 7$ and in $1 \%$ salt concentration. The ability of $B$. aryabhattai to survive and proliferate in harsh conditions is an important factor in their success as inoculants for industrial production of biotechnological products. Since this is a new strain in Bangladesh, more advance research for a deeper understanding about this bacterial strain is needed to improve their production for biotechnological applications.

\section{REFERENCES}

Arrhenius, S. 2009. The Spreading of Life throughout the Universe. Journal of Cosmology, 1. 9199.

Bergey, D. H., Krieg, N. R. and Holt, J. G. 1984. Bergey's manual of systematic bacteriology. Baltimore, MD: Williams \& Wilkins.

Bowers, K. J., Mesbah N. M. and Wiegel, J. 2009. Biodiversity of poly-extremophilic Bacteria: Does combining the extremes of high salt, alkaline $\mathrm{pH}$ and elevated temperature approach a physico-chemical boundary for life? Saline Systems. 23.5-9.

Cappucino, J. G. and Sherman, N. 2001. Microbiology: A laboratory manual (6th ed.). The Benjamin-Cummings Publishing Company Inc. California. USA.

Das, S., Singh, S., Sharma, V. and Soni, M.L. 2011. Biotechnological applications of industrially important amylase enzyme. International Journal of Pharma and Bio Sciences. 2. 486496.

Gupta, R., Beg, Q. and Lorenz, P. 2002. Bacterial alkaline proteases: molecular approaches and industrial applications. Applied Microbiology and Biotechnology 59. 15-32.

Hidri, D. E., Guesmi A. and Najjari, A. 2013. Cultivation-dependant assessment, diversity, and ecology of haloalkaliphilic bacteria in Arid Saline Systems of Southern Tunisia. BioMed Research International. 648141. 1-15.

Horikoshi, K. 1999. Alkaliphiles: Some Applications of Their Products for Biotechnology. Microbiology and Molecular Biology Reviews. 63(4). 735-750

Hoyle, F. and Wickramasinghe, N. C. 2000. Astronomical Origins of Life: Steps Towards Panspermia. Kluwer Academic Publishers, Dordrecht, Netherlands.

Hoyle, F. and Wickramasinghe, N.C. 1977. Identification of the $\square 2,200 \mathrm{~A}$ interstellar absorption feature, Nature, 270, 323-324.

Hoyle, F. and Wickramasinghe, N.C. 1981. Evolution from Space. J.M. Dent and Son, London, UK. 35-49. 
Islam, M. R., Mondol, O. K., Rahman, M. S., Billah, M. M., Rahman, M. S. and Zohora, U.S. 2017. Screening of $\alpha$-amylase producing bacteria from tannery wastes of Hazaribag, Bangladesh. 5. 1-10.

Jaeger, K. E. and Eggert T. 2002. Lipases for biotechnology. Current Opinion in Biotechnology. 13(4). 390-397

Koc, M., Cokmus, C. and Cihan, A. C. 2015.The genotypic diversity and lipase production of some thermophilic bacilli from different genera. Brazilian Journal of Microbiology. 46. 1065-1076.

Kohlmann, K.L., Nielsen, S.S., Steenson, L.R. and Ladisch, M.R. 1991. Production of proteases by psychrotrophic microorganisms.Journal of Dairy Science. 74. 3275-3283.

Lee, D.W., Koh, Y.S., Kim, K.J., Kim, B.C., Choi, H.J., Kim, D.S., Suhartono, M.T. and Pyun, Y.R. 1999. Isolation and characterization of a thermophilic lipase from Bacillus thermoleovorans ID-1. FEMS Microbiology Letters. 179. 393-400.

$\mathrm{Li}, \mathrm{X}$. and $\mathrm{Yu}, \mathrm{HY}$. 2012. Purification and characterization of an organic-solvent-tolerant cellulase from a halotolerant isolate, Bacillus sp. L1. Journal of Industrial Microbiology and Biotechnology. 39: 1117-1124

Line, M.A. 2007. Panspermia in the context of the timing of the origin of life and microbial phylogeny. International Journal of Astrobiology. 6. 249-254.

Miller, G.L. 1959. Use of dinitrosalicylic acid reagent for determination of reducing sugar. Analytical chemistry. 31. 426-428.

Napier, W., Wickramasinghe, J. and Wickramasinghe, N. 2007. The origin of life in comets. International Journal of Astrobiology. 6. 321-323.

Neesa, L., Jahan, N., Khan, A. A. N. and Rahman, M. S. 2017. Cellulolytic Bacillus may or may not Produce $\beta$-Glucosidase due to their Environmental Origin - A Case Study. Journal of Microbiology and Biotechnology Research. 7. 30-38.

Rahman, M. S., Islam, M. R., Mondol, O. K., Rahman, M. S., Sabrin, F. and Zohora, U. S. 2018. Screening of protease producing bacteria from tannery wastes of leather processing industries at Hazaribag, Bangladesh. Jahangirnagar University Journal of Biological Sciences. 7. 23 -34.

Ray, S., Datta, R., Bhadra, P., Chaudhuri, B. and Mitra, A.K. 2012. From space to earth: Bacillus aryabhattai found in the Indian sub-continent. Bioscience Discovery. 3. 138-145.

Shivaji, S., Chaturvedi P., Begum Z., Pindi P.K., Manorama R., Padmanaban D.A., Shouche Y.S., Pawar S., Vaishampayan P., Dutt, C.B.S., Datta G.N., Manchanda R.K., Rao U.R., Bhargava, P.M. and Narlikar J.V. 2009. Janibacter hoylei sp. nov., Bacillus isronensis sp. nov. and Bacillus aryabhattai sp. nov., isolated from cryotubes used for collecting air from the upper atmosphere. International Journal of Systematic and Evolutionary Microbiology. 59. 2977-2986.

Souza, P. M. and Magalhaes, P. O. 2010. Application of microbial $\alpha$-amylase in industry - A review. Brazilian Journal of Microbiology. 41(4). 850-861.

Wainwright, M., FawazAlshammari, F. and Alabri, K. 2010. Are microbes currently arriving to Earth from space. Journal of Cosmology. 7. 1692-1702.

Wickramasinghe, C. 2010. The astrobiological case for our cosmic ancestry. International Journal of Astrobiology. 9. 119-129.

Wickramasinghe, J.T., Wickramasinghe, N.C. and Napier, W.M. 2009. Comets and the Origin of Life. World Scientific Publishing, London, UK.

Wickramasinghe, N.C., 1974. Formaldehyde Polymers in Interstellar Space, Nature. 252. 462-463.

Wood, T. M. and Bhat, K.M. 1988. Methods for measuring cellulase activities. Methods in enzymology. 160. 87-112. Academic Press. 